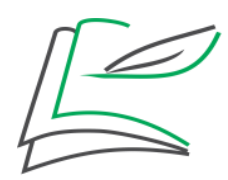

Entretextos

Entretextos 21(1): jan./jun. 2021

ISSN 1519-5392 UEL

DOI: $10.5433 / 1519-5392.2021 v 21$ n1.p.51

\title{
O meme sob uma perspectiva semântico-enunciativo
}

\author{
The meme under a semantic-enunciative perspective
}

El meme desde una perspectiva semántica-enunciativa

\author{
Juliemerson José da Silva* Dhttps://orcid.org/0000-0002-7028-0269 \\ Luciani Dalmaschio* (iDhttps://orcid.org/0000-0002-3652-7299
}

\begin{abstract}
RESUMO: Devido à grande dinamicidade e capacidade de ressignificação da linguagem e suas transformações no meio digital, nossa pesquisa elege os memes como objeto de estudo, no intuito de compreender esse fenômeno linguístico sob a perspectiva da Semântica da Enunciação. Sendo assim, o presente trabalho propõe investigar como se manifesta a (re)construção dos efeitos de sentido, por meio do meme, a partir de um olhar semântico-enunciativo. Em termos mais abrangentes, nosso objetivo principal consiste em analisar os domínios estruturais bem como aqueles de ordem histórico-social que sustentam o processo de significação dos memes. No que tange ao tema e à delimitação do objeto de estudo, procuramos abordar os memes relacionados à ex-presidente do Brasil, Dilma Rousseff. A elaboração do corpus da pesquisa foi realizada por meio de entradas de busca na plataforma Google utilizando do processo metodológico das redes enunciativas (DIAS, 2018). Desse modo, nossa análise permitiu identificar que a (re)construção da significação de um meme se dá por meio da relação entre semelhanças e diferenças e que, associada à sua capacidade metamórfica e adaptativa, tais fenômenos digitais se sustentam na relação entre os domínios estruturais da língua e os de ordem sócio-histórica.
\end{abstract}

PALAVRAS-CHAVE: Meme. Semântica da Enunciação. Significação.

ABSTRACT: Due to the great dynamism and capacity of language resignification and its transformation in digital environment, this research defines memes as its study object, aimed to comprehend this linguistic phenomenon in the perspective of Semantics of Enunciation. This way, this paper intends to investigate how the manifestation of the (re)construction of the effects of meaning, through memes, is done considering a Semantic-Enunciative perspective. More broadly, our goal consists in analyzing the structural domains as well as those of social-historical order that support the meaning process of memes. About the theme and the delimitation of the study object, we decided to analyse the memes related to the ex-president of Brazil, Dilma Rouseff. The constitution of the survey corpus was done by searches in the Google platform, using the methodological process of Enunciative Networks (DIAS, 2018). This way, our analysis allowed us to identify that the (re)construction of meaning in memes happens through the similarities and

\footnotetext{
* Mestre em Letras pela Universidade Federal de São João del-Rei - UFSJ. Atualmente é Professor do ensino regular na Prefeitura de Conselheiro Lafaiete. E-mail: juliemerson.silva@hotmail.com

* Doutora em Linguística pela Universidade Federal de Minas Gerais - UFMG. Atualmente é Professora Adjunta da Universidade Federal de São João del-Rei - UFSJ. E-mail: lucianid@ufsj.edu.br
} 
differences and that associated with their metaphorical and adaptative capacity, these digital phenomena are supported by the structural domains of language and those of a social-historical order.

KEYWORDS: Meme. Semantics of Enunciation. Meaning.

RESUMEN: Debido a la gran dinámica y capacidad de resignificación del lenguaje y sus transformaciones en el entorno digital, nuestra investigación elige memes como objeto de estudio, para comprender este fenómeno lingüístico desde la perspectiva de la Semántica de la Enunciación. Así, el presente trabajo propone investigar cómo la (re) construcción de los efectos del significado se manifiesta, a través del meme, desde una mirada semántica-enunciativa. En términos más amplios, nuestro objetivo principal es analizar los dominios estructurales, así como los de órdenes histórico-sociales que apoyan el proceso de significación del meme. Con respecto al tema y la delimitación del objeto de estudio, tratamos de abordar los memes relacionados con la ex presidenta de Brasil, Dilma Rousseff. La elaboración del corpus de investigación se realizó a través de entradas de búsqueda en la plataforma de Google utilizando el proceso metodológico de las redes enunciativas (DIAS, 2018). De esta manera, nuestro análisis nos permitió identificar que la (re) construcción del significado de un meme ocurre a través de la relación entre similitudes y diferencias y que, asociado con su capacidad metamórfica y adaptativa, tales fenómenos digitales se mantienen en la relación entre dominios estructurales del lenguaje y de un orden socio-histórico.

PALABRAS CLAVE: Meme. Semántica de la Enunciación. Significado.

\section{Introdução}

Novas relações comunicacionais permeiam o mundo e novas tecnologias são integradas ao processo discursivo. Um novo ambiente para práticas sociais se instaura, incorporando o meio digital como componente quase que indispensável para as relações corriqueiras, uma vez que a praticidade e a velocidade têm se tornado fatores fundamentais para os novos modelos de expressão linguística. Nesse âmbito tecnológico, tais mudanças requerem também novos olhares sobre a compreensão do uso da linguagem. Ao adentrar as plataformas digitais, observamos uma grande quantidade de mecanismos inovadores que articulam diversas formas de expressões linguísticas e mobilizam uma participação em rede entre seus usuários. Diante desse cenário, o presente artigo pretende lançar um olhar linguístico para alguns desses aspectos. Sendo assim, por se tratar de um fenômeno relativamente novo e próprio desse ambiente, nossa pesquisa elege os memes como objeto de estudo, no intuito de compreender essa manifestação linguística nas redes digitais sob a perspectiva da Semântica da Enunciação.

Desse modo, o objetivo deste trabalho consistiu em analisar o meme como acontecimento enunciativo verificando suas regularidades e especificidades linguístico- 
estruturais a partir do seu movimento de (re)significação que se dá no processo de enunciação. Por conseguinte, buscamos relacionar as propriedades fundantes de um meme (fidelidade, fecundidade, longevidade) a alguns dos pressupostos da Semântica da Enunciação no que diz respeito ao movimento linguístico de (re)construção e deslocamento de efeitos de sentido.

No que tange ao tema e à delimitação do objeto de estudo, procuramos abordar os memes relacionados à ex-presidente do Brasil, Dilma Rousseff. O recorte temático foi realizado tendo em vista duas grandes variáveis. A primeira se refere ao nível de produtividade de memes desenvolvidos sobre o tema em questão e a segunda tem ligação direta com linha de pesquisa à qual se vinculou a proposta de trabalho que deu origem a este artigo: discurso e representação social. Para realização da pesquisa, os memes foram coletados da internet por meio do mecanismo de busca do Google e da rede social Twitter. Por esse procedimento, selecionamos aqueles cujo domínio referencial estivesse sustentado pelas seguintes formas linguísticas: "tchau, querida", "dobrar a meta", "estocar vento", "mulher sapiens" e "saudar a mandioca", que foram utilizadas como entrada de busca nos ambientes digitais descritos.

Para sistematizar nossa análise, utilizamos uma metodologia que apresenta as ocorrências organizadas em rede. $\mathrm{O}$ conceito de rede enunciativa foi desenvolvido por Dias (2018) "como um procedimento de demonstração das relações entre unidades articuladas, por meio de semelhanças e diferenças entre construções linguísticas" (DIAS, 2018 , p. 36). Para o autor, esse procedimento possibilita observar o funcionamento da língua mediante a viabilidade da produção de enunciados que são entrelaçados por uma relação de compatibilidade e de contrastes.

Em relação à composição estrutural do artigo, primeiramente apresentaremos um percurso de construção conceitual do termo "meme". Em seguida, discutiremos os pressupostos da Semântica da Enunciação, a fim de analisarmos o meme enquanto acontecimento enunciativo que produz significação na relação entre a estabilidade e a mudança. 


\section{0 que são os memes?}

Meme é um termo criado pelo etólogo Richard Dawkins (2007) cuja proposta foi elaborar uma palavra que, em analogia aos genes, pudesse representar uma unidade de transmissão cultural. $O$ conceito teve origem a partir dos estudos evolucionistas que têm o gene como componente orgânico do ser humano, uma molécula capaz de criar cópias de si mesma. Cópias, por vezes, imprecisas demonstrando certa variedade no processo de replicação.

Associando transmissão cultural à transmissão genética, Dawkins (2007) defende a ideia de que o gene não é a única entidade replicadora do nosso planeta. Dessa forma, os memes se configuram como "melodias, ideias, slogans, as modas no vestuário, as maneiras de fazer potes ou construir arcos" (DAWKINS, 2007, p. 330), que se propagam "saltando de cérebro para cérebro através de um processo que, num sentido amplo, pode ser chamado de imitação" (DAWKINS, 2007, p. 330). Entretanto, apesar de apresentarem tais atributos, os memes são transmitidos sob uma forma modificada, associados com algo situado entre o campo do repetível e do irrepetível. Isso evidencia que "a transmissão do meme parece estar sujeita à mutação e à mistura contínuas" (DAWKINS, 2007, p. 334).

Dessa forma, Dawkins (2007) estabelece três propriedades para os memes: longevidade, fecundidade e fidelidade de cópia. A longevidade está ligada ao tempo em que o meme perdura em determinado espaço, tornando-se veículo que se preserva (DAWKINS, 2007). Segundo Dawkins (2007), a fecundidade tem mais importância que a longevidade devido a sua função difusora relacionada ao grau de aceitação de um determinado público e a sua capacidade de sobrevivência. Assim, a fecundidade é constituída através da propagação e da produtividade de um meme das mais diferentes maneiras. Por conseguinte, alguns memes podem se espalhar rapidamente, atingindo sucesso no que se refere à fecundidade em um curto espaço de tempo, mas sem uma longa durabilidade (DAWKINS, 2007), assumindo a característica de algo efêmero. Similar à tendência evolutiva das moléculas, quanto maior a longevidade, maior também será a fecundidade de um meme. Por fim, a fidelidade de cópia está associada à capacidade de precisão e imitação que o meme possui. Entretanto, Dawkins (2007) afirma se encontrar em um terreno pouco firme a respeito dessa característica visto que os memes são 
transmitidos de forma modificada em algum grau, não se caracterizando em replicadores de alta fidelidade. Ou seja, se estabelece aqui uma ideia de relativização da fidelidade, uma vez que não repetimos ideias de formas fixas, mas por um processo de reapropriação reformulamos propósitos.

Segundo Dawkins (2007), suas pretensões em discutir a cultura humana eram quase inexistentes de tão modestas. Apesar disso, toda a sua abordagem inicial sobre os memes é de fundamental importância para discutirmos o que são os memes como fenômenos linguísticos no meio digital, levando em considerações características conceituais bastante pertinentes.

A fim de ampliar nossos conceitos sobre os memes como fenômenos da linguagem digital, recorremos à professora de comunicação e jornalismo, Limor Shifman (2014), para quem os memes não apenas se espalham como uma espécie de vírus de forma passiva, mas se propagam de pessoa para pessoa moldando e refletindo posicionamentos sociais. Em um mesmo movimento de replicação e imitação, o meme também se modifica e reconstrói dizeres. Shifman (2014) propõe, então, a diferença entre memes e virais na internet. Enquanto os virais apenas se espalham e se propagam como cópias, os memes se difundem através da variabilidade e modificação textual, como uma coleção de textos que faz referência a algo em uma espécie de versão modificada, uma reconstrução de algo já dito.

Filiamo-nos a perspectiva de que, por meio de relações enunciativas, os memes estabelecem vínculos entre si e não podem ser tratados como "unidades isoladas e discretas, mas como blocos de construção de culturas complexas, entrelaçadas e interagindo umas com as outras" (SHIFMAN, 2012, p. 189) ${ }^{1}$. Desse modo, é imprescindível ao meme estabelecer relações em rede, sustentando a ideia de que "não é um fim em si mesmo, mas um meio" (CHAGAS; TOTH, 2016, p. 231), não apresentando, assim, significado intrínseco. $O$ meme é produtivo enunciativamente e só pode ser examinado em conjunto através de relações que são estabelecidas "a partir de seus elementos discursivo e associativo" (CHAGAS; TOTH, 2016, p. 215). Ou seja, os memes só podem ser considerados memes se examinados em redes enunciativas, demonstrando

\footnotetext{
${ }^{1}$ Tradução livre de: "memes are not treated here as isolated, discreet units, but as the building blocks of complex cultures, intertwining and interacting with each other" (SHIFMAN, 2012, p. 189).
} 
um variado repertório linguístico entre a estabilidade e a mudança. A fim de elucidar essas reflexões, apresentaremos um dos memes que serão analisados neste artigo.

No dia 16 de março de 2016, o juiz Sérgio Moro autorizou a divulgação de um grampo telefônico contendo uma conversa entre o ex-presidente Luiz Inácio Lula da Silva e a então presidente na época, Dilma Rousseff. Lula estava sendo investigado pela Operação Lava Jato e Dilma o nomeou como ministro chefe da Casa Civil. Segundo Sérgio Moro, Lula já sabia ou pelo menos desconfiava de estar sendo investigado pela Polícia Federal. Assim, essa nomeação seria uma estratégia de retardar as investigações contra o ex-presidente. No final da conversa divulgada, Lula se despediu de Dilma utilizando a expressão "Tchau, querida", que acabou se propagando por toda a internet.

Figura 1 - Transcrição da conversa entre Lula e Dilma

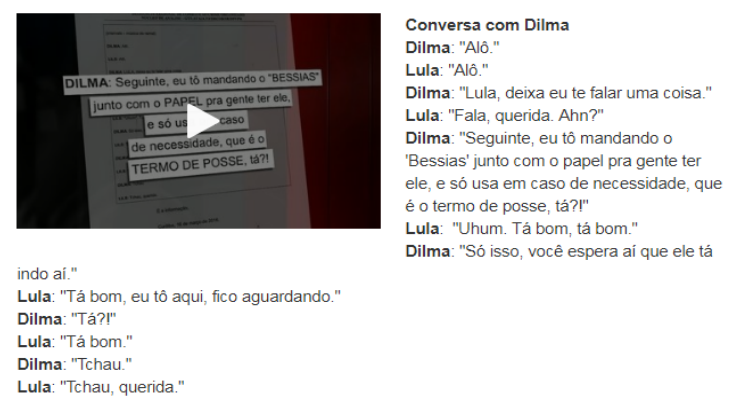

Fonte: Castro, Nunes e Netto (2016).

A expressão "Tchau, querida" não apenas se tornou um viral na internet, mas um meme devido as suas constantes remodelagens e (re)apropriações que projetaram variados efeitos de sentido. 0 meme em questão ganhou uma proporção ainda maior em função da votação na câmara dos deputados que decidiu dar prosseguimento ao processo de impeachment de Dilma Rousseff, no dia 17 de abril de 2016 (MARTELLO, 2016). Após a votação na câmara, o meme "Tchau, querida" começou a se replicar na internet repercutindo na deposição de Dilma.

Figura 2 - Deputados levam ao plenário cartazes contendo a expressão "Tchau, querida"

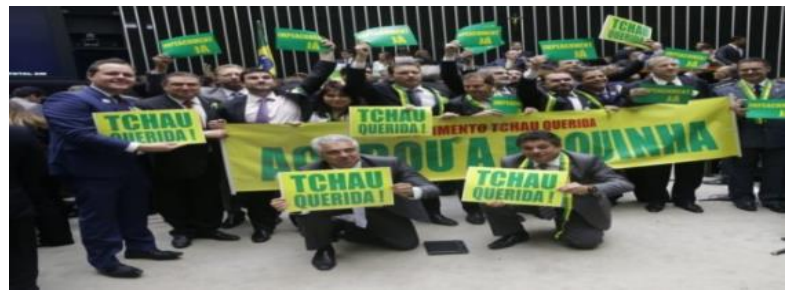

Fonte: Deputados... (2016). 
Em (2), a expressão dita por Lula a Dilma na conversa telefônica foi resgatada e utilizada com outra finalidade. Assim, "Tchau, querida" passou de uma saudação carinhosa para ser usada, ironicamente, por aqueles favoráveis ao impeachment da expresidente como uma expressão que enaltecia a sua saída. Vejamos o que ocorre, agora, em (3):

Figura 3 - Meme "Tchau, querida" associado a músicas

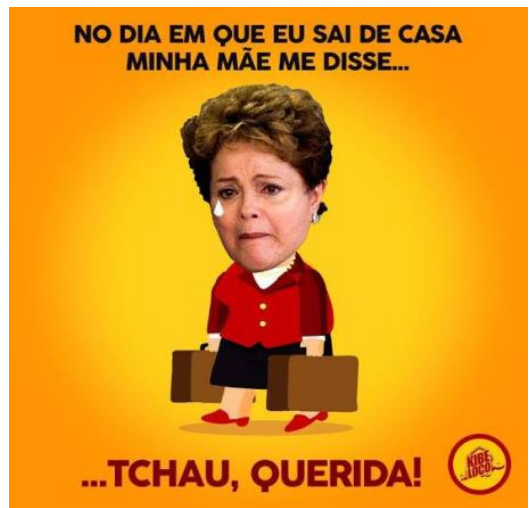

Fonte: 'Tchau... (2016).

O meme (3) apresenta elementos que evidenciam características situadas entre a estabilidade e a mudança e não pode ser considerado um viral, uma vez que ocorreu uma reconfiguração do modelo matriz, instaurando, assim, uma rede de enunciados que a cada enunciação (re)constrói efeitos de sentido. Assim, a fidelidade se manifesta na expressão "Tchau, querida!", permitindo que se estabeleça um vínculo com a conversa telefônica que originou o meme. Já a fecundidade se evidencia na associação da expressão "Tchau, querida" a uma música.

Passaremos, agora, a apresentar nossas filiações relacionadas à Semântica da Enunciação, explorando conceitos e postulações teóricas que serão associadas aos memes.

\section{Pressupostos da Semântica da Enunciação}

Ao discorrer sobre diferentes teorias da enunciação, Flores e Teixeira (2005) apresentam a multiplicidade dos modos de ver a enunciação, em conformidade com diversos autores. Tal pluralidade teórica faz com que Flores e Teixeira (2005) postulem uma Linguística da Enunciação enquanto um campo de estudos da linguagem que tem como objeto de análise a própria enunciação. A partir dessas considerações, eles afirmam 
que os autores que se debruçam sobre o termo enunciação desenvolvem um trabalho "que é, antes de tudo, um estudo da semântica da língua". Tendo em vista tal pensamento, eles apontam um questionamento: "Então é a linguística da enunciação uma semântica?" (FLORES; TEIXEIRA, 2005, p. 97). Para nós, sim.

Enquanto semanticistas, assumimos a posição de que a linguagem significa 0 mundo e tudo o que se diz é construído na/pela linguagem. Desse modo, tomamos a semântica como o campo de estudo que lida com a construção dos efeitos de sentido, por meio da relação entre o elemento linguístico e uma concepção histórica e enunciativa da linguagem. Ou seja, "uma semântica que considera que a análise do sentido da linguagem deve localizar-se no estudo da enunciação, do acontecimento do dizer" (GUIMARÃES, 2017, p. 9).

Segundo Guimarães (2018), a semântica é uma disciplina cujo objetivo é estudar o funcionamento da linguagem e não pode ser tratada como propriedade externa à língua. Dessa maneira, a semântica se ocupa em trabalhar a significação relacionada a uma concepção histórica constitutiva do linguístico. Isto é, a semântica à qual nos filiamos não pensa as palavras de forma isolada em si mesmas no estado de dicionário, de forma estática e, sim, possibilita examinar a significação enquanto algo processual, móvel, "produzida pela enunciação, por alguém, de algum material de linguagem específico" (GUIMARÃES, 2018, p. 14). Sendo assim, é na relação entre a Semântica e Enunciação que as formas linguísticas são mobilizadas a significar (DIAS, 2018). Logo,

[...] o tratamento da enunciação deve se dar num espaço em que seja possível considerar a constituição histórica do sentido, de modo a que a semântica se formule, claramente, como uma disciplina do campo das ciências humanas, fora de suas relações com a lógica ou a gramática pensadas ou como o matematizável ou como uma estrutura biologicamente determinada (GUIMARÃES, 2017, p. 10).

Sob esse viés, podemos perceber a importância da articulação entre as formas linguísticas e os aspectos histórico-sociais para a produção dos efeitos de sentido. Guimarães (2018) ressalta essa agregação como indispensável para os estudos semântico-enunciativos ao afirmar que o sentido se constitui por meio da "integração do enunciado, e seus elementos linguísticos, ao texto" (GUIMARÃES, 2018, p. 43). Sendo assim, para Guimarães (2018), o enunciado se configura como unidade de análise, 
demonstrando, ao mesmo tempo, duas características que, por mais que pareçam opostas, se relacionam: uma consistência interna, proporcionada pela morfologia e elementos linguísticos na relação de predicação; e uma independência relativa, uma vez que a palavra precisa ser integrada ao acontecimento para ganhar significação. Ou seja,

Estas características são consideradas em relação ao todo de que o enunciado faz parte num acontecimento de enunciação. Ou seja, a unidade de análise é uma unidade de linguagem encontrada (que está presente) em acontecimentos específicos (GUIMARÃES, 2018, p. 15).

Dessa forma, enquanto a significação se configura como nosso objeto de estudo, o enunciado se caracteriza como unidade de análise e só existe quando dito na enunciação (GUIMARÃES, 2018). Por conseguinte, a partir dessas reflexões relacionadas à produção de sentidos no acontecimento enunciativo, pode-se afirmar que

a significação de um enunciado é afetada por domínios de mobilização na medida em que ele se constitui arregimentado em um campo de enunciação, permitindo a ele adquirir uma identidade social. Tendo em vista essa identidade histórica dos enunciados, eles se submetem a uma identificação, também de ordem social, em que efetivamente travam uma relação de pertinência com outros no campo de enunciação (DIAS, 2018, p. 111).

Dessa maneira, partimos do pressuposto de que "a enunciação, enquanto acontecimento de linguagem, se faz pelo funcionamento da língua" (GUIMARÃES, 2017, p. 15). Ou seja, é a partir do uso que a linguagem se constrói enquanto prática social, produzindo e ressignificando sentidos. Logo, percebemos o acontecimento "como um construto histórico que, por meio de inúmeros entrecruzamentos, é capaz de construir um estado de coisas." (DALMASCHIO, 2015, p. 241-242).

Nessa direção, conforme Guimarães (2017), o acontecimento agencia o sujeito e instaura sua própria temporalidade: passado, presente e futuro. Com efeito, é possível afirmamos que no acontecimento há uma ancoragem no passado representado por rememorações dos sentidos de enunciações por ele recortadas e um futuro responsável pela projeção de sentidos que se desdobrarão em outras enunciações (GUIMARÃES, 2017). Assim, se estabelece uma rede de enunciações de caráter inerentemente histórico, uma vez que a língua carrega marcas do passado, o que evidencia a impossibilidade de 
pensar a linguagem fora de um aspecto relacional.

Logo, associar a ideia de rede a de acontecimento corresponde a entendê-lo como algo fluido, sem marcações polarizadas, que não segue uma linha precisa de sucessividade entre passado, presente e futuro. Significar, por essa via, efetiva-se em um entrecruzamento de enunciações que, mobilizadas pelo acontecimento, temporalizam: resgatam, presentificam e projetam dizeres (GUIMARÃES, 2017).

A partir dessas reflexões, passemos a analisar os memes relacionados a Dilma Rousseff enquanto acontecimento que constrói significação na relação entre a estabilidade e a mudança em um processo semântico-enunciativo.

\section{0 meme enquanto acontecimento enunciativo: fidelidade, fecundidade e longevidade}

Nesta seção, iremos examinar os campos da repetibilidade (resistência) e da irrepetibilidade ${ }^{2}$ (mudança) presentes nos memes associando-os aos pressupostos da Semântica da Enunciação. Em virtude disso, desenvolveremos o que foi discutido na fundamentação teórica, analisando o meme como acontecimento enunciativo e verificando suas regularidades e especificidades linguístico-estruturais a partir do seu movimento de (re)significação que se dá no processo de enunciação. Sendo assim, apresentaremos o meme, para, em seguida, examiná-lo por meio de suas características no que diz respeito aos conceitos de fidelidade relativo à regularidade, fecundidade relacionado à irregularidade e longevidade referente à prospecção enunciativa. A fim de iniciarmos a discussão, voltemos ao meme (3) apresentado anteriormente.

No meme (3), observamos a expressão "Tchau, querida" - marca de fidelidade integrada, como objeto verbal, ao processo de fecundidade que se realiza pela presença do enunciado "No dia em que eu sai de casa minha mãe me disse..." O enunciado da parte superior do meme representa um trecho da música "No dia em que eu saí de casa" da dupla sertaneja Zezé Di Camargo e Luciano que, originalmente, se completa com o predicado: "disse filho vem cá". Logo, em (3), observamos que os movimentos de fidelidade e fecundidade são necessários para a constituição do meme, que se distancia da mensagem carinhosa de Lula a Dilma e se aproxima da ideia de despedida irônica, em

\footnotetext{
2 Vale ressaltar que por "irrepetível" não tomamos aquilo que se torna imutável, mas aquilo que, de maneira provisória, se regulariza em determinados usos.
} 
um movimento de tensão entre o repetível e o irrepetível. Trata-se, portanto, do mesmo e do diferente atuando, juntos, na atualização do efeito de sentido no processo de enunciação. A imagem da ex-presidente com o semblante triste segurando as malas reforça a ideia de despedida por meio do tom humorístico, o que evidencia o caráter multimodal desse fenômeno linguístico.

Figura 4 - Meme "Tchau, querida" relacionado a formas de sedução

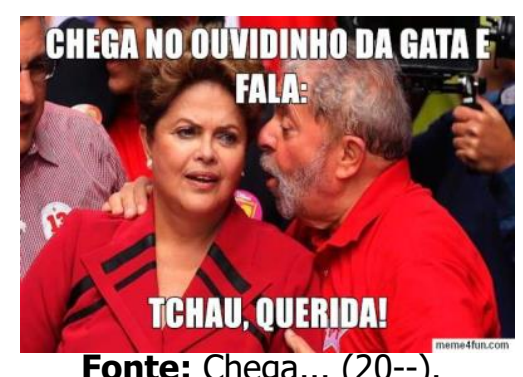

Notamos no meme presente na Figura (4) que o aspecto da fidelidade se manifesta, novamente, pela repetição da expressão "Tchau, querida". Tal expressão representa a característica imitativa do meme responsável por estabelecer a conexão com os outros memes. Além da presença dessa materialidade linguística que permite construir uma rede de conexões, a fidelidade também se manifesta na ordem simbólica do dizer ao produzir um efeito de sentido sustentado pelo mesmo domínio referencial do exemplo da Figura (3): ironizar a saída de Dilma da presidência. No caso da Figura (4), o meme apresenta sua fecundidade ao demonstrar uma espécie de dica para "cantadas" que visa seduzir alguém através do enunciado "Chega no ouvido da gata e fala", tendo "Tchau, querida!" como objeto da forma verbal "fala". Desse modo, percebemos que "Tchau, querida" deixa de ser uma simples expressão de despedida para se tornar um meme em função de suas diversas replicações que retratam uma correlação entre fidelidade e fecundidade. Logo, só a partir da relação entre regularidades (fidelidade) e mudanças (fecundidade) é que o meme se constitui. O caráter multimodal desse meme (4) também reforça tal relação, ou seja, o material verbal dialoga com o não verbal na medida em que temos, mais uma vez, Lula dizendo à Dilma a expressão "Tchau, querida". Nessa direção, a fidelidade é reforçada pela repetição da expressão (Tchau, querida), pelo mesmo sujeito. Entretanto, o processo de ressignificação se materializa uma vez que, diferentemente da conversa telefônica, a expressão "Tchau, querida" aborda de maneira 
humorística o impeachment de Dilma Rousseff.

Vale ressaltar que embora a constituição mórfica da expressão "Tchau, querida" seja mantida, o seu funcionamento sintático é alterado tanto em (3) quanto em (4): o caráter de vocativo cede lugar ao de complemento verbal, de acordo com os estudos de bases tradicionais. Assim, para que haja consistência interna, "Tchau, querida" precisa integrar um enunciado maior, sem o qual o efeito de sentido dos memes (3) e (4) não encontraria ancoragem referencial para se manifestar, conforme descrevemos na rede enunciativa presente no Quadro 1:

Quadro 1 - "Tchau, querida" mudança sintática

\begin{tabular}{|c|c|}
\hline No dia em que eu saí de casa minha mãe me disse & \multirow{2}{*}{ Tchau, querida } \\
\hline Chega no ouvido da gata e fala & \\
\hline
\end{tabular}

Fonte: Elaborado pelos autores.

Sobre esse tipo de mudança sintático-estrutural que pode ocorrer na constituição dos memes, vejamos outro exemplo, observando agora o que ocorre em relação à entrada de busca da expressão geradora de outro meme, constituinte de nosso corpus: "Estocar vento".

No final de setembro de 2015, em um pronunciamento na sede da ONU, nos Estados Unidos, Dilma Rousseff sugeriu a criação de uma tecnologia para "estocar vento", a fim de contribuir para a produção sustentável de energia. Essa fala de Dilma repercutiu na internet e, consequentemente, fomentou a produção de memes (GÓES, 2015). Um exemplo é o que está ilustrado na Figura (5):

Figura 5 - Meme "Estocar vento" relativo a gases intestinais

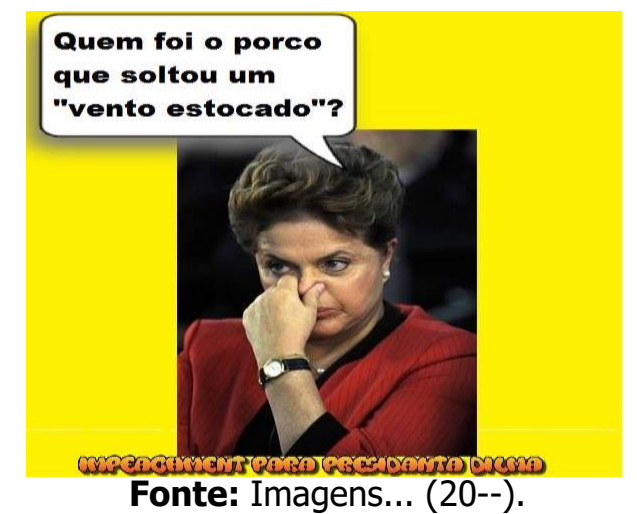


Notamos que a expressão "estocar vento" é nominalizada para "vento estocado", o que modifica relativamente a fidelidade, conforme demonstrado no Quadro 2:

Quadro 2 - "Estocar vento" mudança sintática

\begin{tabular}{|l|l|}
\hline Estocar vento & verbo + objeto \\
\hline Vento estocado & nome + adjunto \\
\hline
\end{tabular}

Fonte: Elaborado pelos autores.

Contudo, mesmo com essa mudança sintática, é possível associar a expressão (vento estocado) ao dizer de Dilma (estocar vento). Isso é reforçado pela presença de sua imagem seguida de um balão de fala, sugerindo a autoria do dizer. $\mathrm{O}$ aspecto da fecundidade que ressignifica a palavra "vento" pode ser percebido por meio da imagem de Dilma tapando o nariz em um gesto que demonstra incômodo em relação ao cheiro. Esse sentido é reforçado pela palavra "porco" que, sendo associado ao ser humano, remete à falta de educação e imundícies. Assim, o enunciado "Quem foi o porco que soltou "vento estocado?", associado à imagem de Dilma cobrindo o nariz, reafirma a fecundidade do meme (5) que (re)significa "vento estocado" para a ideia de gases intestinais.

Como forma de dar prosseguimento à análise do processo de reconfiguração sintática que pode ocorrer com as expressões que originaram os memes de nossa pesquisa, lancemos, agora, um olhar para a forma linguística: "mulher sapiens".

No dia 23 de junho de 2015, em discurso no lançamento dos primeiros jogos mundiais dos povos indígenas, Dilma Rousseff proporcionou dois momentos de descontração que marcaram sua fala e, consequentemente, potencializaram memes nas redes digitais (JUBÉ, 2015). No primeiro momento, Dilma, ao celebrar os alimentos do cultivo tradicional dos índios, afirma: "Aqui hoje estou saudando a mandioca, acho uma das maiores conquistas do Brasil". No segundo momento, ao discutir sobre a evolução humana a partir da criação da bola, a ex-presidente exibe uma bola feita de folhas de bananeira como símbolo de nossa evolução e afirma: "Quando nós criamos uma bola destas, nós nos transformamos em homens sapiens ou mulheres sapiens". As falas de 
Dilma referentes a "saudar a mandioca"- como um importante alimento para o Brasil - e a criação da espécie "mulher sapiens" - para descrever a evolução humana proporcionam a criação de diversos memes que se propagaram e se reconfiguraram de muitas maneiras. Observemos, a princípio, os exemplos (6) e (7), que se constituíram por meio da expressão "mulher sapiens".

Figura 6 - Meme "Mulher sapiens" relativo a um programa de televisão

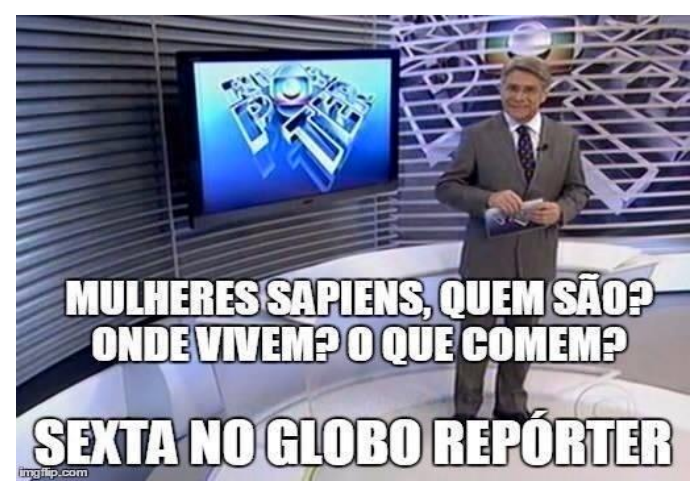

Fonte: Mulher... (2015).

Na Figura (6), observamos a presença da expressão "mulheres sapiens" que permite o meme (6) ser identificado dentro de uma cadeia de enunciações. Sendo assim, pelo fato de o meme não ser uma unidade isolada e só ser examinado em conjunto, a fidelidade funciona como elo dessa rede. Notamos que a expressão "mulheres sapiens" aparece no plural e traz uma característica mais geral ao termo relativo à "espécie evolutiva". A fecundidade dialoga com esse aspecto mais geral da expressão "mulheres sapiens" e se evidencia por meio das perguntas, seguidas da data em que serão discutidas: "Quem são? Onde vivem? O que comem? Sexta no Globo Repórter". A linguagem não verbal reforça a fecundidade do meme (6), uma vez que apresenta o cenário referente a um programa jornalístico da Rede Globo chamado "Globo Repórter" que exibe diversas reportagens sobre saúde, ciência, natureza, destinos e aventuras exóticas do Mundo. Dessa forma, por meio do humor, "mulheres sapiens" é mencionada como pauta do programa, uma vez que no meme (6) ela se apresenta como uma espécie que precisa ser explorada em relação à existência, habitação e comportamentos alimentares. Nesse caso, "mulheres sapiens" ocupa o lugar de tópico do enunciado, ou seja, aparece em posição sintática distinta daquela apresentada na fala de Dilma, onde se articula com o verbo "transformar", ocupando o lugar de objeto. Segundo Pontes 
(1987), o papel funcional do tópico é o de chamar atenção para um elemento. Decorre desse fato a expressão ser utilizada como chamada principal para o assunto que será debatido no programa.

Vale destacar que o termo "mulher sapiens", com referência direta a Dilma Rousseff, aparece no título de um livro do jornalista Celso Arnaldo Araujo (7) que, com tom humorístico, propõe satirizar as falas da ex-presidente por meio de seus raciocínios confusos e de sua inaptidão para a oratória. Sendo assim, ao observar os pronunciamentos de Dilma, estabelece o "Dilmês" como o idioma pertencente à "mulher sapiens" (Dilma).

Figura 7 - Meme "Mulher sapiens" no título de um livro

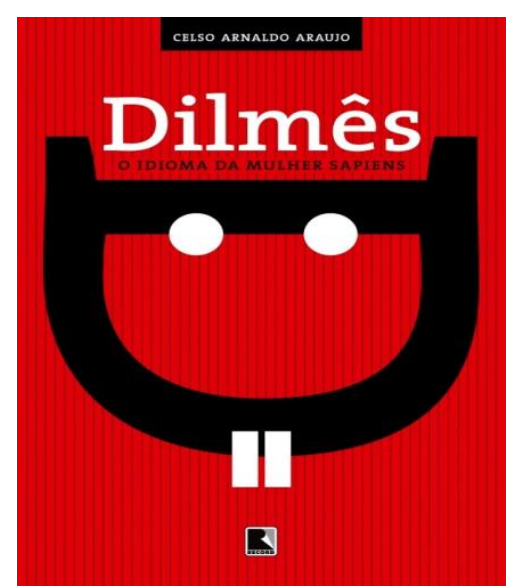

Fonte: Lopes (2016).

Nesse caso, "mulher sapiens" ocupa no enunciado o lugar de adjunção, perdendo o estatuto de destaque tópico que recebe em (6), já que no título do livro essa ênfase é materializada pelo nome "Dilmês". Observemos, no Quadro 3, a movimentação sintática de "mulher sapiens", descrita nos exemplos apresentados:

Quadro 3 - "Mulher sapiens" mudança sintática

\begin{tabular}{|l|l|}
\hline \multirow{4}{*}{ Mulher(es) sapiens } & Objeto indireto (fala de Dilma) \\
\cline { 2 - 2 } & Tópico (predicativo/sujeito) (6) \\
\cline { 2 - 2 } & Adjunto adnominal (7) \\
\hline
\end{tabular}

Fonte: Elaborado pelos autores. 
Devido à capacidade metamórfica dos memes, outras mudanças de caráter linguístico-estruturais, além daquelas relacionadas ao campo da sintaxe, podem ocorrer. Vejamos, desta vez, como alterações morfológicas podem se manifestar na constituição de um meme sem, contudo, invalidar o aspecto da fidelidade, próprio desse fenômeno linguístico.

Figura 8 - Meme "Tchau, querida" relacionado a Eduardo Cunha

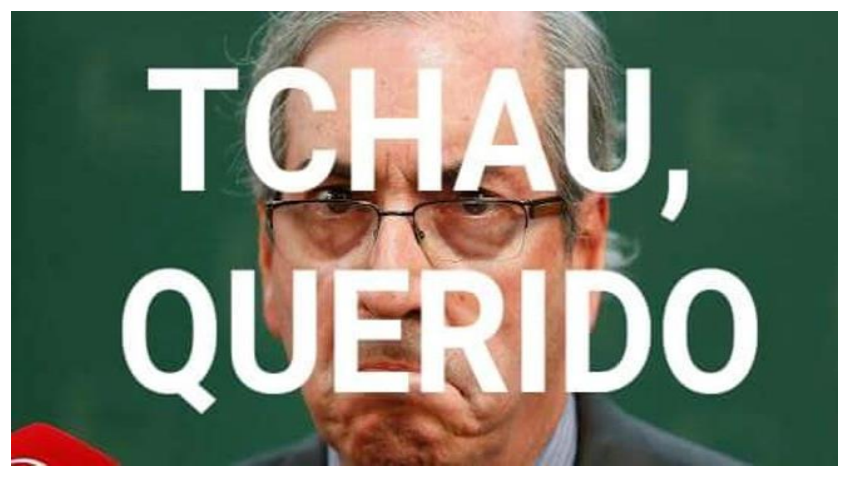

Fonte: \#tchauquerido... (2016).

Percebemos nesse meme (Figura 8) a presença da forma linguística "Tchau, querido" associada à imagem de Eduardo Cunha, ex-presidente da câmara dos deputados. Enquanto presidente da câmara, Cunha foi o responsável por autorizar o processo de impeachment de Dilma Rousseff. Contudo, o ministro do Supremo Tribunal Federal (STF) Teori Zavascki determinou o afastamento de Eduardo Cunha do mandato de deputado federal e da presidência da cámara (OLIVEIRA; RAMALHO, 2016) alguns dias após a votação do afastamento de Dilma. Assim, o meme da Figura (8) mantém fidelidade com "Tchau, querida" por meio da expressão "Tchau, querido", na medida em que a mudança da desinência de gênero"a" para a desinência de gênero"o", fazendo referência à figura de Eduardo Cunha, representa uma forma de tornar fecunda a expressão inicial sem, contudo, repeti-la de forma idêntica. A legitimação dessa troca envolve, dentre outros aspectos, o caráter multimodal que se manifesta pela imagem presente no meme. Ademais, a fecundidade também está presente no referencial em que se situa o meme, uma vez que não é mais Dilma a figura ironizada pelo afastamento do cargo, e sim Cunha. Dessa forma, a fecundidade faz com que o meme assuma uma suscetibilidade enunciativa, evidenciando, assim, uma vulnerabilidade a entrelaçamentos 
contínuos e transformações de sentidos. Assim, também no campo da morfologia, o meme pode apresentar uma fidelidade relativa, como ocorre na troca de "a" para "o" (8), e sempre estará sujeito a modificações constantes. Isso pode ser percebido com mais detalhamento no exemplo (9) em que a Revista Veja utiliza em sua capa o meme "Tchau, querida", associando-o à sua variação "Tchau, querido", a fim de relacionar os afastamentos de Cunha e Dilma (9), a partir de uma despedida irônica:

Figura 9 - Meme "Tchau, querida" na capa da Revista Veja

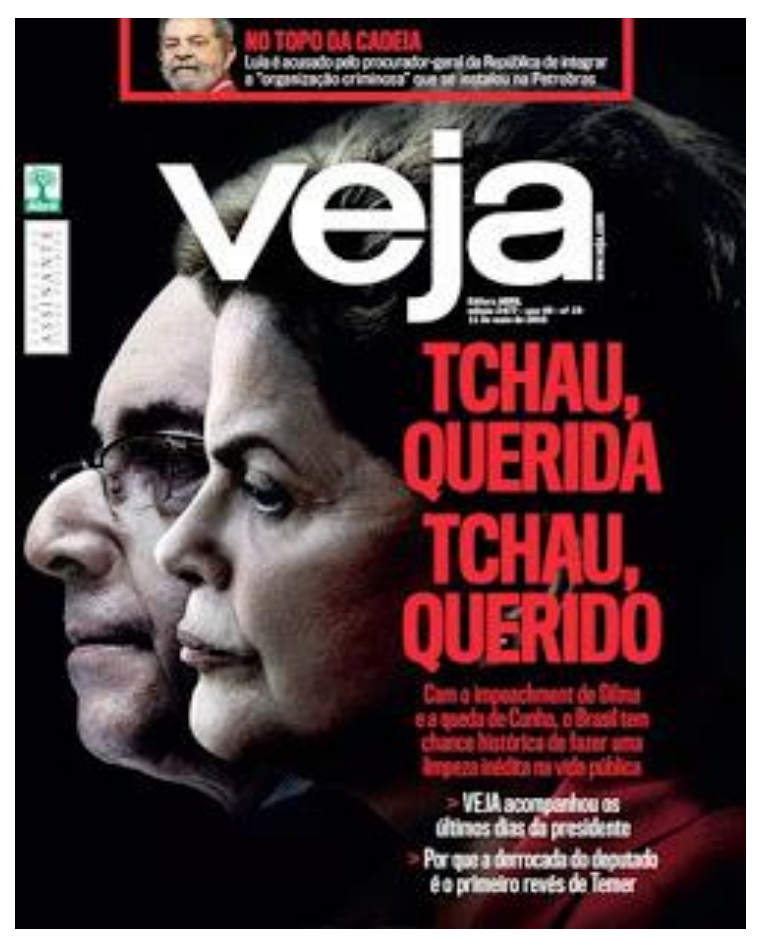

Fonte: D-Revistas Magazine 3 .

As alterações de caráter morfológico, presentes nos dois exemplos, podem ser assim representadas:

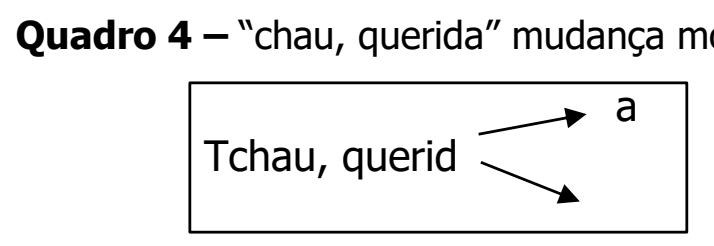

Fonte: Elaborado pelos autores.

\footnotetext{
3Disponível em: http://d-revistasmagazine.com/2013/04/veja-la-revista-de-brasil/. Acesso em: 19 de jul. 2019. Link fora
} 
É interessante observar como essa mudança morfológica para indicação de gênero (não) ocorre na Figura (10):

Figura 10 - Meme "Tchau, querida" relativo a Jean Wyllys

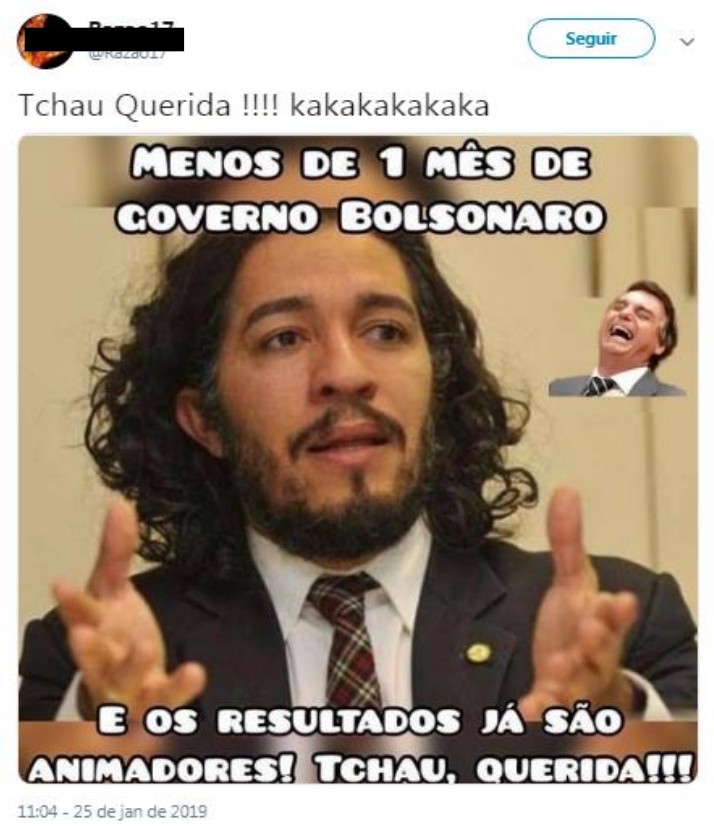

Fonte: Razão 17 (2019).

No meme (10), coletado no Twitter, podemos perceber que a expressão "Tchau, querida" foi associada à imagem do ex-deputado federal Jean Wyllys, demonstrando o caráter de fecundidade do meme. O meme da Figura (10) não trata da questão do impeachment de Dilma, mas ironiza a decisão de Jean Wyllys, em janeiro de 2019, de não tomar posse do seu novo mandato em função de ameaças que vinha sofrendo (BARROS, 2019). Ou seja, a fecundidade possibilitou a ressignificação do meme (10) que sofreu modificação tanto na orientação argumentativa quanto no aspecto formal. Dessa forma, a fidelidade é marcada pela expressão "Tchau, querida" que mantém a ideia de se despedir ironicamente de alguém. Já a fecundidade/longevidade se manifestam pelo enunciado "Menos de 1 mês de governo Bolsonaro e os resultados já são animadores!" associado à imagem do ex-deputado federal.

Sendo assim, enquanto a fidelidade permite que "Tchau, querida" seja associada a uma rede de enunciações, identificando relações com suas replicações, a fecundidade se constitui pela difusão e produtividade do meme. Desse modo, considerando que o 
meme "Tchau, querida" teve sua origem em 2016, podemos dizer, ao observar o meme (10), divulgado em 2019, que a longevidade é determinada pela regularidade de uso que o meme assume entre a estabilidade e a mudança. Ou seja, são as replicações, reproduções e remodelagens discursivas que contribuem para a preservação e continuidade de um meme, como no exemplo (10) que mantém a expressão "Tchau, querida" e a ressignifica em outra enunciação. Logo, a longevidade marca a relação entre a preservação e a transformação na medida em que cria possibilidades de combinações por meio da suscetibilidade enunciativa, a fim de ultrapassar o "modelo matriz", mesmo após um tempo relativamente longo em relação a sua origem.

É importante perceber que mesmo havendo uma identidade formal entre a expressão inicial "Tchau, querida" e a forma linguística em causa no exemplo (10), essa identificação também assume um caráter argumentativo, uma vez que, assim como em (8), o vocativo de despedida está direcionado a um homem e não a uma mulher. Tratase, portanto, da materialização da ironia por meio da utilização de uma marca feminina para a designação de um homem, em função de críticas à orientação sexual por ele assumida. Entendemos, assim, que a mudança morfológica está presente na repetição do mesmo (Tchau, querida), diante da exigência do diferente (Tchau, querido).

Quadro 5 - "Tchau, querida" versus" Tchau, querida" - mudança morfológica

\begin{tabular}{ll|}
\hline Tchau, querida & Tchau, querido \\
\hline
\end{tabular}

Fonte: Elaborado pelos autores.

Passemos a analisar, neste momento, como alterações lexicais também podem ocorrer no processo de propagação dos memes, de modo a não comprometer o aspecto de fidelidade desse fenômeno linguístico. 
Figura 11 - Meme "Tchau, querida" relacionado a eliminações de participantes do BBB 19

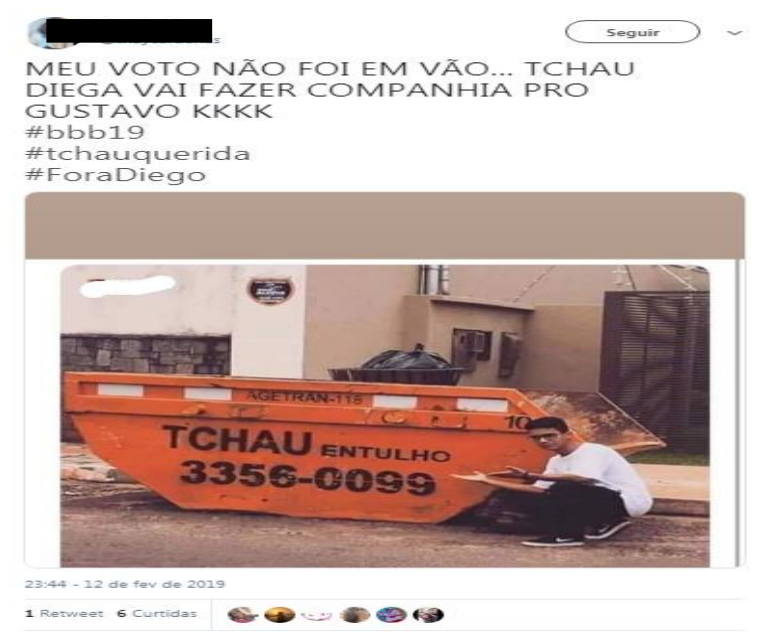

Fonte: Thainá (2019).

Percebemos no meme (11) o caráter da longevidade que demonstra não só a capacidade de sobrevivência no tempo, mas a relação entre a manutenção e a variação que contribuem para a continuidade do uso, favorecendo, assim, sua fecundidade. Tal reflexão dialoga com a ideia de Dawkins (2007) de que quanto maior a longevidade, maior a fecundidade e vice-versa. No meme (11), a expressão "Tchau, querida" vem acompanhada da cerquilha (\#) produzindo uma hashtag ${ }^{4}$ e evidenciando o aspecto da fidelidade. Tal expressão (Tchau, querida) está associada à eliminação de um participante em reality show que é reforçada pela materialidade verbal "Tchau Diega", "\#ForaDiego" e pela imagem onde está registrada a forma linguística "Tchau Entulho". O sentido de resto contido na palavra "entulho" dialoga com a palavra "querida", uma vez que ambas se articulam a "tchau" e possuem um sentido negativo e irônico em relação à saída do participante. Seguindo o processo de realizar a articulação da palavra "tchau" com outros vocábulos que não "querida", vejamos o meme a seguir.

\footnotetext{
${ }^{4}$ Hashtag é uma palavra-chave antecedida pela cerquilha (\#) que as pessoas geralmente utilizam para identificar o tema do conteúdo que estão compartilhando nas redes sociais. A adesão delas se tornou popular no Twitter e se disseminou para as maiores mídias sociais da atualidade.
} 
Figura 12 - Meme "Tchau, querida" relativo a piadas sobre atraso

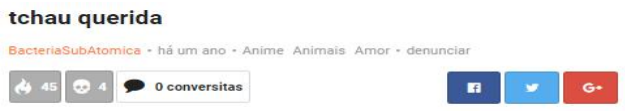

\section{TCHAU COLLOR}

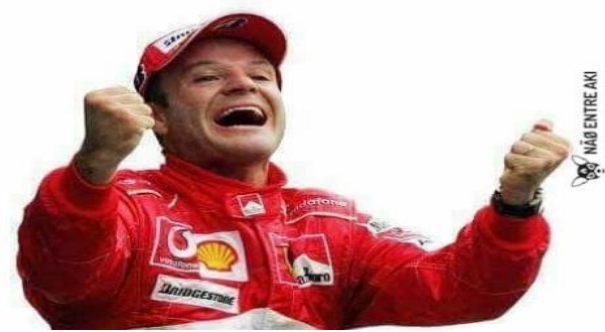

Fonte: Não Entre Aki

Na Figura (12), temos a expressão "Tchau Collor" seguido da imagem do automobilista brasileiro de Fórmula 1, Rubens Barrichello. Isso, mais uma vez, evidencia a fecundidade do meme cuja mutabilidade está ligada a uma piada corrente na internet (ROSSET, 2017) que associa a imagem de Barrichello à lentidão e aos atrasos. Por conseguinte, vemos um jogo de sentidos nesse meme (12), uma vez que não temos mais a palavra "querida", mas sim o sobrenome de Fernando Collor de Mello que renunciou ao cargo de presidente da república em 29 de dezembro 1992 antes de ser condenado, por meio de um processo de impeachment, pelo senado federal. Tal construção satírica se manifesta pela associação da ideia de atraso, contida na figura de Barrichello, ao sobrenome "Collor", expressando que o piloto se encontra ainda no processo de impeachment de 1992. Assim, o jogo entre fidelidade (Tchau) e fecundidade (Collor e Rubens Barrichello) constitui o meme (12) e produz significação, sustentado por referenciais históricos relativos a piadas sobre o piloto brasileiro, e aos impeachments de Dilma e Collor.

Dessa forma temos:

Quadro 6 - " Tchau, querida" mudança lexical

\begin{tabular}{|l|l|}
\hline \multirow{4}{*}{ Tchau, querida } & Tchau Diega \\
\cline { 2 - 2 } & Tchau Entulho \\
\cline { 2 - 2 } & Tchau Collor \\
\hline
\end{tabular}

Fonte: Elaborado pelos autores.

\footnotetext{
${ }^{5}$ Disponível em: http://www.naoentreaki.com.br/4924990-tchau-querida.htm. Acesso em: 19 de jul. 2019 link fora.
} 
Não se trata, dessa vez, de uma mudança morfológica e/ou sintática na forma linguística em análise. O que ocorre é um deslocamento léxico, por meio do qual o lugar da palavra "querida" é ocupado por outras palavras que são demandadas pelo acontecimento enunciativo em ato.

Para continuar nossas análises sobre estabilidades e mutações, regularidades e irregularidades, resistência e mudança, examinaremos, agora, o meme "dobrar a meta". Em 2015, na apresentação dos Planos e Metas do Programa Nacional de Acesso ao Ensino Técnico e Emprego (Pronatec Jovem Aprendiz) (DIAS; FOREQUE, 2015), a ex-presidente Dilma Rousseff, ao tentar explicar o aumento de oportunidades oferecidas pelo governo, esclarecendo que o programa não é regido por metas, fez a seguinte afirmação: "Nós não vamos colocar uma meta. Nós vamos deixar uma meta aberta. Quando a gente atingir a meta, nós dobramos a meta" (DILMA..., [20--]). Essa afirmação é confusa, uma vez que Dilma fala sobre não estipular metas, mas em seguida exprime o desejo de deixar a meta aberta para ser atingida e, consequentemente, dobrada. Assim, esse conflito lógico-semântico presente no pronunciamento da ex-presidente se tornou um meme, se propagando por toda a internet, conforme pode ser exemplificado em (13).

Figura 13 - Meme "Dobrar a meta" relativo a atrasos em obras governamentais

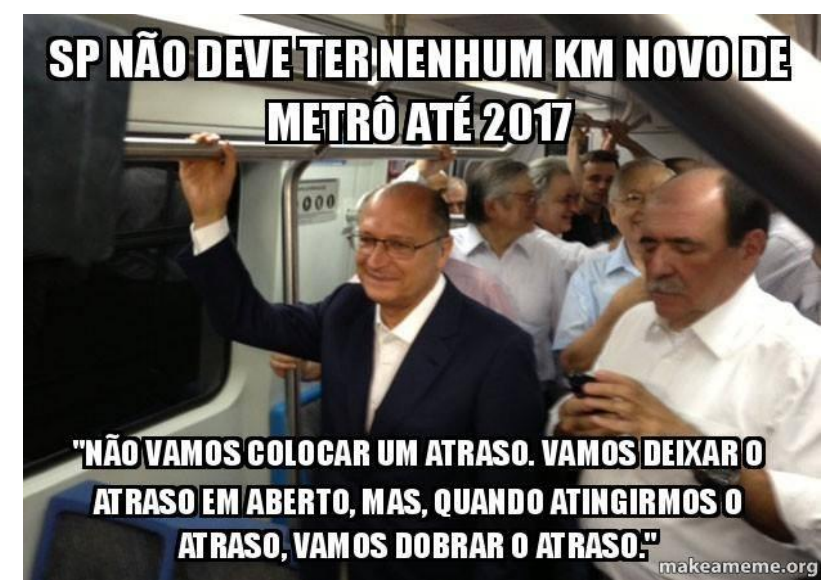

Fonte: A Meta... (2015).

Conforme vimos afirmando, entendemos a fidelidade como aquilo que se mantém e permite ao meme ser reconhecido dentro de uma rede de enunciados. Contudo, a fidelidade pode se manifestar em diferentes níveis, seja em maior ou menor grau. Observamos que no meme (13) a fecundidade manifesta-se na imagem de Geraldo 
Alckmin, no enunciado "SP não deve ter nenhum Km de metrô até 2017" e na palavra "atraso" que substitui a palavra "meta" do "enunciado matriz" pertencente à Dilma Rousseff. Sendo assim, mesmo sem a palavra meta no meme (13), é possível reconhecêlo dentro da rede de enunciações, uma vez que a fidelidade é marcada pelo encadeamento confuso do enunciado a partir das expressões "vamos colocar", "vamos deixar aberto(a)", "atingir(mos)" e "dobrar", reforçando a ideia relacionada ao congelamento das obras de metrô em São Paulo. Dessa maneira, a exemplo do que apresentamos no Quadro 6, a alteração léxica ocorrida entre "meta" e "atraso" atualiza o efeito de sentido suscitado pelo meme.

Quadro 7 - "Dobrar a meta" mudança lexical 1

Dobrar a meta Dobrar o atraso

Fonte: Elaborado pelos autores.

Ainda no que se refere ao grau de fidelidade e às mudanças de ordem lexicais, examinemos os memes que seguem:

Figura 14 - Meme "Dobrar a meta" relativo a drogas

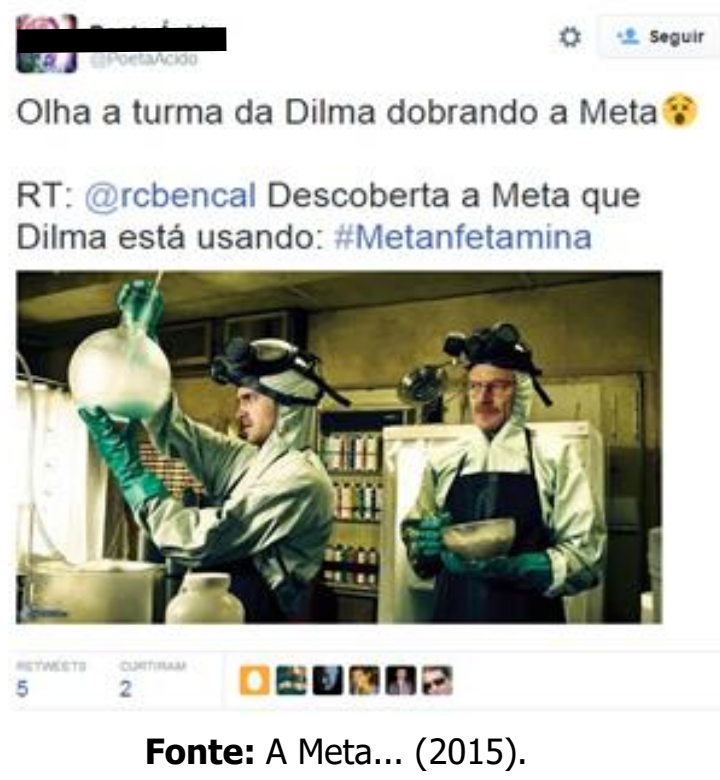

Na Figura (14), percebemos mais um meme que ultrapassa um "modelo matriz", mas preserva o termo "dobrar a meta" - variando a forma verbal - o que possibilita sua 
identificação na rede de enunciados, reforçando a ideia de que o meme não é um texto que exista fora de suas relações com outros textos. Esse meme também se apoia no caráter multimodal para produzir significação na relação entre o repetível e o irrepetível. Em (14), temos a expressão "dobrando a meta" sendo associada como ação do sujeito "turma da Dilma". Tomando a fidelidade como ancoragem, o meme encontra terreno fértil para tornar-se fecundo, por meio da (re)construção de sentido da palavra "meta" que não significa mais objetivo ou propósito, e sim a abreviação de metanfetamina, uma droga sintética, ilícita, de ação estimulante do sistema nervoso central. Desse modo, o meme (14) associa "meta" à droga e relaciona a "turma da Dilma" a manipuladores do estimulante. A imagem que acompanha o meme (14) reforça o processo de (re)construção de "meta", visto que é relativa a uma série de televisão estadunidense chamada Breaking Bad que retrata a história de um professor de química que transforma sua van em um laboratório de metanfetamina.

Aqui, poderíamos dizer que também estamos diante de um processo de construção linguística do meme que se sustenta em uma mudança léxica, como exemplificado em (13). Entretanto, nos parece que a forma linguística "metanfetamina", que substituiu o nome "meta" (alvo) no lugar de objeto do verbo "dobrar", passou por um processo mais elaborado de qualificação enunciativa, uma vez que em sua forma abreviada é tomada como sinônimo do substantivo que originalmente ocupa aquele lugar. Dessa forma, a troca lexical poderia ser assim ilustrada:

Quadro 8 - " Dobrar a meta" mudança lexical 2

Dobrar a meta $\longleftrightarrow$ Dobrar a (meta)nfetamina

Fonte: Elaborado pelos autores.

Mais um exemplo de deslocamento lexical apresentado pelos memes pode ser ilustrado no exemplo a seguir. 
Figura 15 - Meme "Estocar vento" em resposta ao ex-presidente Lula

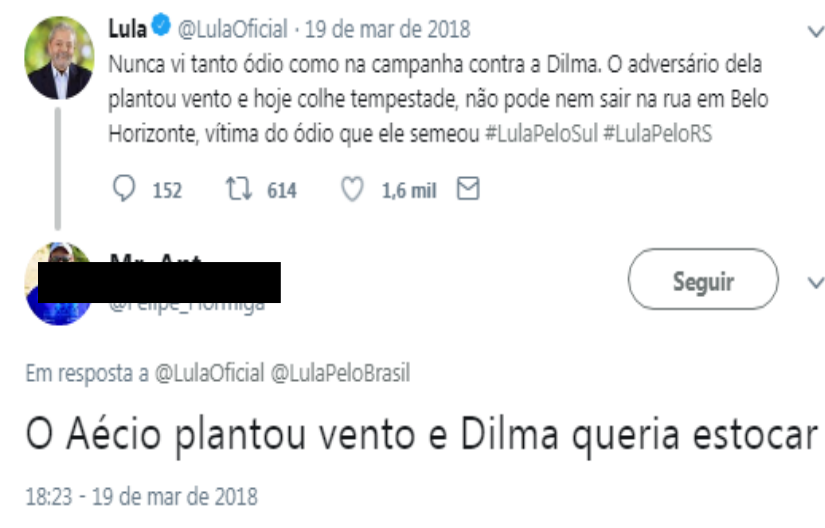

Fonte: MR ANT (2018).

Na Figura (15), temos um tweet que responde a uma publicação do perfil do expresidente Lula no Twitter com o seguinte enunciado: "O Aécio plantou vento e Dilma queria estocar". Lula, em sua publicação, aborda o ódio que Dilma vinha sofrendo nas eleições de 2018 e utiliza um provérbio bíblico ("O adversário dela plantou vento e hoje colhe tempestade"), a fim de defender sua parceira de partido, uma vez que, para Lula, Dilma é vítima do ódio que seu adversário (Aécio) "semeou" no estado de Minas Gerais ("Belo Horizonte"). Na resposta a Lula (15), observamos que o enunciado "O Aécio plantou vento e Dilma queria estocar" se constrói a partir da reconfiguração do provérbio mencionado pelo ex-presidente. Notamos que a palavra "vento", objeto direto do verbo plantar, é associada anaforicamente ao verbo "estocar" como ação de Dilma. Desse modo, a fidelidade se estabelece pela relação entre "Dilma", "estocar" e "vento". Tal relação não é configurada materialmente de forma direta com verbo "estocar" e seu complemento "vento". A fidelidade é construída em meio à fecundidade que ressignifica o provérbio "Quem planta vento, colhe tempestade" mencionado por Lula, constatando que o "vento" que se planta não é mais "colhido" como no provérbio, mas sim "estocado". Consideramos que o jogo léxico entre "plantar vento" e "estocar vento" é fundamental para a produção do efeito de sentido do enunciado.

Nessa direção, podemos dizer que o meme tem semelhanças com o provérbio em função de seu caráter difuso e imitativo. Contudo, o meme é constantemente modificado devido a sua suscetibilidade enunciativa e sua capacidade de condensar sentidos. Por conseguinte, a palavra "vento", presente no provérbio bíblico "quem planta vento, colhe 
tempestade", agencia o falante e oferece a ele regularidades linguísticas para (re)significar o meme "estocar vento". A seguir, temos mais exemplo que reforça essa reflexão:

Figura 16 - Meme "Estocar vento" na (re)construção de um provérbio

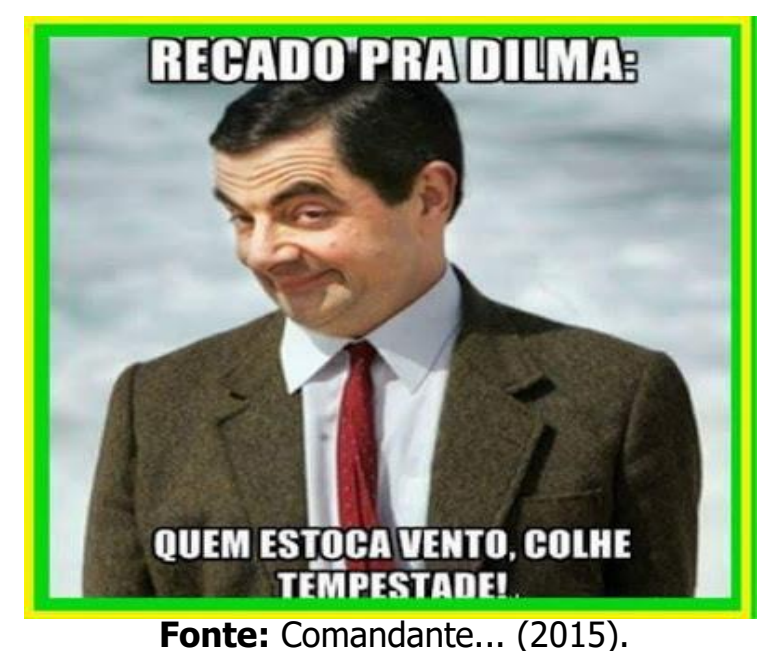

Percebemos no meme (16) a substituição do verbo "plantar" (planta) - presente no provérbio - pelo verbo "estocar" (estoca), relacionado ao meme. Dessa forma, a constituição do meme se dá na configuração política entre a fidelidade ("estoca vento") e a fecundidade (provérbio). Esses exemplos parecem demonstrar, mais uma vez, que o falante é agenciado por essa tensão entre semelhanças e diferenças linguísticas para a produção de efeitos de sentido.

A rede enunciativa, explicitada a seguir, expressa o jogo lexical que possibilita o efeito de humor de (16):

Quadro 9 - " Estocar vento" mudança lexical

\begin{tabular}{|l|l|l|l|}
\hline estocar & \multirow{2}{*}{ vento } & & colher tempestade \\
\cline { 1 - 2 } plantar & & & \\
\hline
\end{tabular}

Fonte: Elaborado pelos autores.

Além de mudanças sintáticas, morfológicas e lexicais, os memes podem apresentar outro tipo de alteração linguística, e, ainda assim, preservar a característica de fidelidade em sua constituição. Vejamos o que ocorre no exemplo da Figura (17). 
Figura 17 - Meme "Dobrar a meta" em uma perspectiva metalinguística

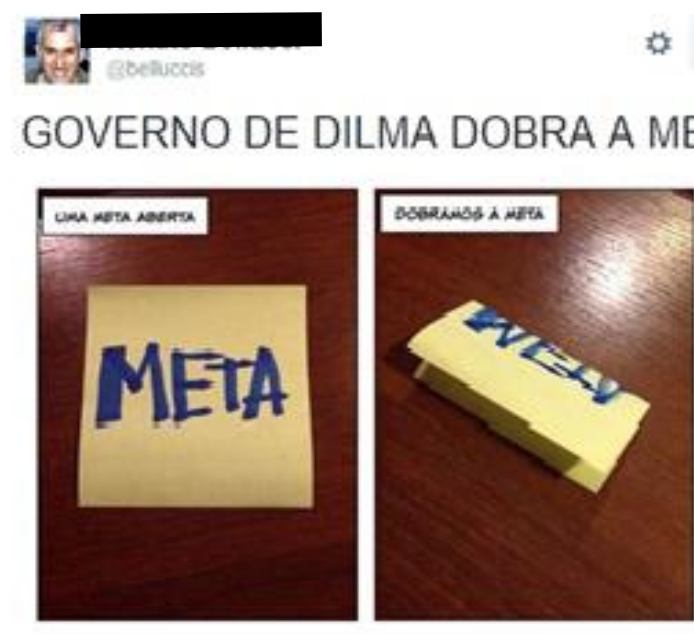

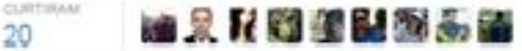

Fonte: A Meta... (2015).

A fim de ilustrar as ações do governo para dobrar a meta, o meme se apoia no recurso da multimodalidade apresentando, de maneira humorística, a palavra "meta" escrita no papel e sendo exibida de duas formas: "aberta" no sentido de distendida e visível e "dobrada" que se distancia da ideia de duplicar objetivos para significar virar e curvar. Ou seja, meta passa a ser lida em uma perspectiva puramente metalinguística, como uma palavra escrita em um papel. Assim, "dobrar a meta" significa "dobrar o papel" onde a palavra está escrita para, consequentemente, "dobrar a palavra". Por conseguinte, a fidelidade, representada pela regularidade dos termos "dobra a meta", "uma meta aberta" e "dobramos a meta", possibilita a fecundidade, que expande o sentido desses termos para ações do governo Dilma, apoiando-se, conforme explicitamos, no caráter multimodal do meme (17). Tal associação ressignifica as palavras "meta", "aberta" e "dobra(mos)", a fim de projetar efeitos de sentidos diversos e construir pertinência com outros enunciados. Portanto, o processo de fecundidade se dá por meio do deslocamento de uma regularidade, propiciando, assim, a reprodutibilidade, a propagabilidade e a adequabilidade dos memes no meio digital, tornando-os suscetíveis a reconfigurações. Decidimos nomear o tipo de mudança que ocorre com o exemplo (17), como mudança de caráter semântico, conforme representado a seguir: 
Quadro 10 - " Dobrar a meta" mudança de caráter semântico

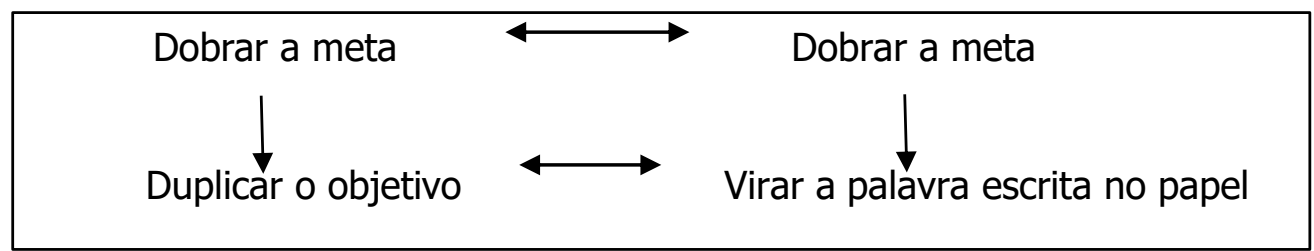

Fonte: Elaborado pelos autores.

Entendemos que os demais tipos de mudança (sintática, morfológica e lexical) também realizam (re)orientações semânticas, por isso optamos por dizer que se trata não de uma mudança semântica e sim de uma mudança"de caráter semântico", uma vez que envolve fenômenos classificados tradicionalmente como polissemia e homonímia.

Embora de forma menos polarizada que em (17), no que se refere à variação de efeito de sentido produzida, consideramos que uma mudança de caráter semântico também pode ser percebida em (18):

Figura 18 - Meme "Estocar vento" relativo a alimentos

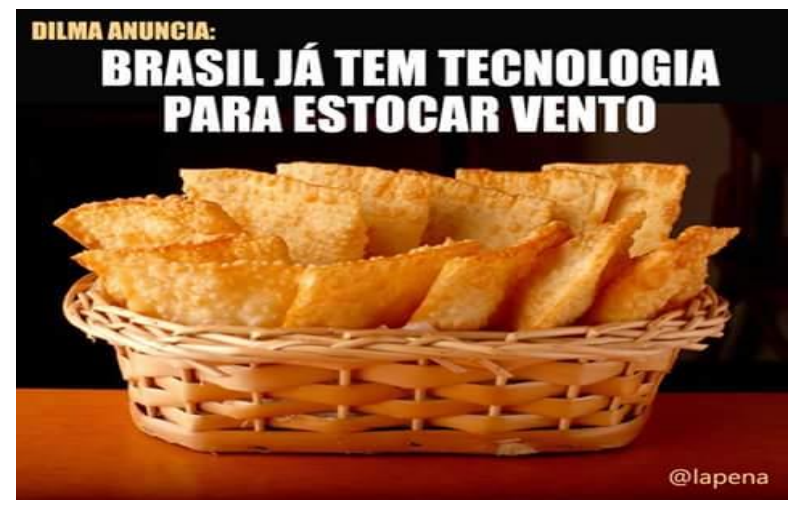

Fonte: Casseta \& Planeta6

Podemos perceber que no meme (18) a significação novamente é construída pela relação entre fidelidade e fecundidade. Temos a expressão "estocar vento" como elemento material de fidelidade associado a um suposto anúncio de Dilma por meio do enunciado "Brasil já tem tecnologia para estocar vento". Aqui a fecundidade também se sustenta no caráter multimodal do texto, uma vez que há a marcação não verbal de um alimento muito conhecido entre os brasileiros: o pastel. Dessa forma, pela associação entre o verbal e a imagem, "estocar vento" não significa mais armazenamento de ar na

${ }^{6}$ Disponível em: http://www.casseta.com.br/lapena/tag/tecnologia-2/. Acesso em: 22 de jul. 2019.Link fora 
produção de energia, mas sim ausência ou escassa quantidade de recheio do pastel, popularmente conhecido como pastel de vento. Assim, a exemplo do que apresentamos no Quadro 10, em (18) também ocorre uma mudança de caráter semântico na expressão "estocar vento", que passa a ser significada da seguinte forma:

Quadro 11 -" Estocar vento" mudança de caráter semântico 1

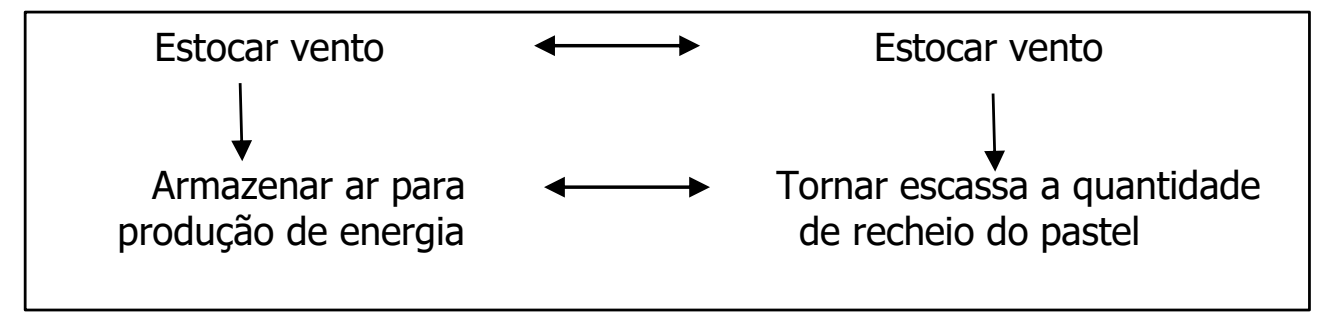

Fonte: Elaborado pelos autores.

Em analogia aos aspectos genéticos, Dawkins (2007) aborda a concepção de replicador associada ao conceito de meme, a fim de demonstrar que tal propagação, assim como as moléculas genéticas, se dá de maneira "imperfeita", ou seja, apresenta uma estabilidade relativa. O que o autor chama de "imperfeição", nós entendemos como um movimento próprio do linguístico, que não se manifesta de outra maneira a não ser pelo deslize sobre já posto. No caso dos memes, esse processo de des/re/construção provoca iterações que são amplificadas com o humor, contribuindo, assim, para a sua propagabilidade.

Em (19), temos mais um exemplo de como a mudança de caráter semântico se manifesta na constituição de um meme.

Figura 19 - Meme "Saudar a mandioca" relativo a cumprimentos

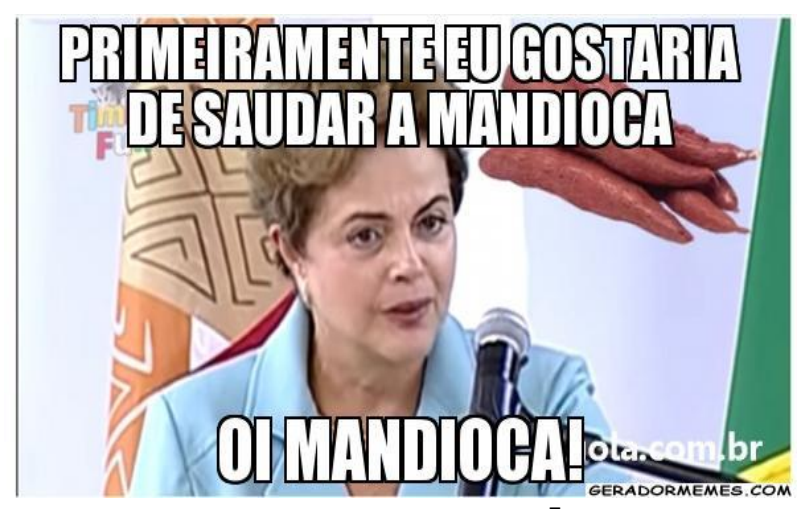

Fonte: X2u Club?

\footnotetext{
${ }^{7}$ Disponível em: https://www.x2u.club/memes-da-mandioca.html. Acesso em: 23 de jul. 2019.
} 
O meme (19) promove um processo (re)significação da expressão "saudar a mandioca", uma vez que movimenta os efeitos de sentido do verbo "saudar", deslocando o sentido de reverenciar/homenagear a mandioca por sua importância - construído por Dilma em seu pronunciamento - para o de cumprimento corriqueiro que se manifesta pela expressão "oi". Sendo assim, a fecundidade, responsável pela mutabilidade, atualiza o verbo "saudar" mantendo, em um movimento de fidelidade, o mesmo objeto verbal ("a mandioca"). Trata-se de um trabalho com a configuração política do sentido na construção do humor.

Quadro 12 -" Estocar vento" mudança de caráter semântico 2

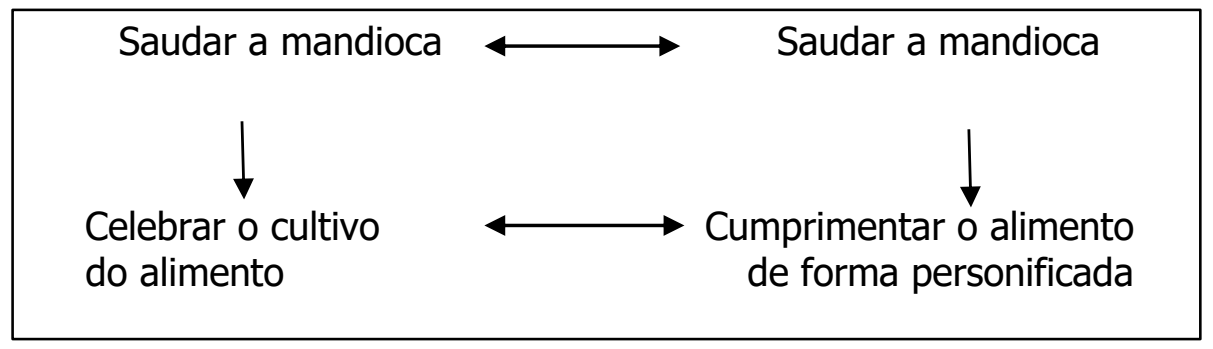

Fonte: Elaborado pelos autores.

É importante dizer que esses tipos de mudanças que acabamos de descrever podem ocorrer de forma concomitante em um mesmo meme, conforme pode ser percebido em (20).

Figura 20 - Meme "Mulher sapiens" associado ao meme "Tchau, querida"

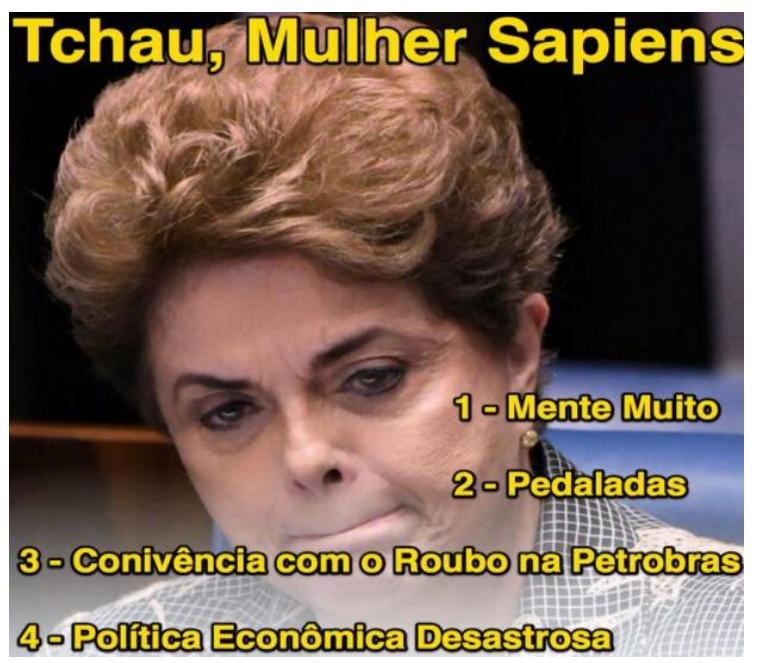

Fonte: Tchau... ([20--]). 
Em relação à fidelidade, notamos no meme (20) a presença da expressão "Mulher Sapiens" associada à imagem de Dilma Rousseff. Já a fecundidade se manifesta pela associação de despedida "Tchau" a essa mulher, o que evidencia uma correlação com o meme "Tchau, querida" que também diz respeito à ex-presidente. A palavra "querida" é substituída pela expressão "Mulher Sapiens" reforçando não só a fecundidade do meme (20), como também uma construção em rede com outros memes referentes a Dilma. 0 fato de um meme ser constituído nessa teia de sentidos se dá justamente pela capacidade de tornar-se estável em meio a mudanças, ou seja, pela capacidade de condensar atualizações e projetar-se para abrigar outras regularizações. Em (20), mudanças sintáticas e lexicais convergiram no enredamento de dois memes. Decorre desse fato compreendermos que o linguístico para se constituir lança mão de um aspecto simbólico e de um aspecto material que convivem em interface, sem que um possa prescindir do outro.

É importante ressaltar que, em nossa perspectiva de análise, as possibilidades e mutações dos memes não são realizadas pelo falante de maneira individual e autossuficiente. Desse modo, o falante é agenciado pelo aspecto da fidelidade, próprio do meme, e, a partir dessas regularidades linguísticas, é capaz de produzir a replicação desse texto, fazendo com que o meme adquira novas proposições e novos formatos, mas sempre mantendo elementos que farão com que ele seja identificado enquanto meme. Logo, é a partir desse jogo enunciativo, que os recursos linguísticos são postos em causa, por meio de investimentos sintáticos, morfológicos, lexicais ou de caráter semântico, conforme analisamos até aqui. Portanto, não consideramos que o falante seja totalmente autônomo na criação de um meme, uma vez que enquanto ser de linguagem ele é agenciado pela língua a dizer. No caso dos memes, postulamos que esse agenciamento se ancora na exigência de fidelidade e, a partir das possibilidades linguísticas que ela oferece, a fecundidade e a longevidade se efetivam.

Atrelada a essa construção em cadeia por meio de imitações e misturas contínuas, a longevidade se torna um elemento capaz de alimentar tais regularidades e sentidos, a fim de que sejam atualizados e projetados por meio do movimento enunciativo. Observemos a Figura (21) a seguir: 
Figura 21 - Meme "Dobrar a meta" relativo à longevidade

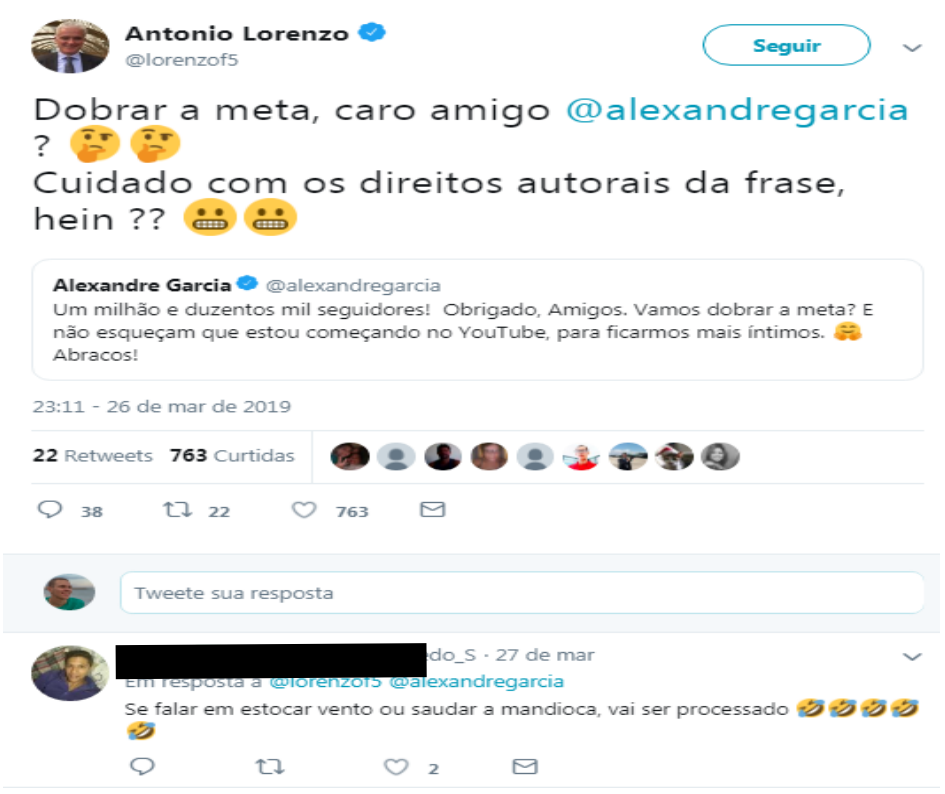

Fonte: Lorenzo (2019).

Na Figura (21), temos um comentário de uma postagem referente ao jornalista Alexandre Garcia que agradece uma marca alcançada em relação ao número de seguidores e que complementa sobre duplicar essa meta por meio do enunciado "Vamos dobrar a meta?". O tweet (21) chama a atenção do jornalista em relação à expressão "dobrar a meta", discutindo, de forma irônica, sobre o cuidado que se deve ter em relação aos direitos autorais dessa expressão. Sendo assim, o tweet (21) coloca o termo "dobrar a meta" como uma expressão cuja autoria deveria ser sempre citada como referência, como origem do dizer. Podemos perceber que, mesmo após, aproximadamente, quatro anos, a expressão "dobrar a meta" traz consigo efeitos de sentidos de enunciações passadas envolvendo a ex-presidente Dilma Rousseff e faz com que os internautas, ironicamente, questionem a ideia de autoria da frase, como se ela pertencesse a Dilma. O comentário, logo abaixo desse, reforça essa ideia ao associar mais duas falas/memes de Dilma "estocar vento" e "saudar a mandioca" à ideia de processo por direitos autorias ("vai ser processado"). Sendo assim, embora sem ser mencionado o nome de Dilma Rousseff, nem mesmo por um pronome, por uma expressão anafórica, ou até mesmo pelo seu antigo cargo, é possível resgatar sua imagem por meio dessas expressões/meme.

A partir dessas reflexões nos questionamos como isso é possível, uma vez que "Dobrar a Meta" e "Tchau, querida", por exemplo, são construções linguísticas 
corriqueiras. A expressão "dobrar a meta" é composta por um verbo e um sintagma nominal e traz o significado relacionado a ultrapassar objetivos que foram estabelecidos. Já "Tchau, querida" significa uma despedida carinhosa, visto que o termo "querida", em seu sentido dicionarizado, significa "estimada", apreciada com conotação positiva. Contudo, nós não nos pautamos na ideia estática de significado, uma vez que significar corresponde, para a perspectiva à qual nos filiamos, a um processo dinâmico realizado a partir do acontecimento enunciativo. Com efeito, "Dobrar a meta" e "Tchau, querida", assim como qualquer meme, participam de um movimento memético de reconfiguração do que já foi por meio da fecundidade que lhe é própria. Desse modo, em função de sua disseminação e re(significação), os memes são capazes de estabilizar sentidos, a partir da regularidade de usos, mesmo sendo propensos a alterações constantes e, por isso, são capazes de condensar significações em um mesmo objeto simbólico. Assim, embora apresente picos de utilização - geralmente próximos das datas em que se "originaram" a longevidade de um meme pode ser analisada em função dessa condensação de sentidos que se manifesta na relação entre fidelidade e fecundidade. Portanto, é a partir dessa relação de contrastes e semelhanças que os memes apresentam uma dilatação de seu sentido dicionarizado e assumem um caráter condensativo de novos efeitos de sentido evocados na enunciação.

\section{Considerações finais}

Desse modo, a partir das reflexões sobre as propriedades fundantes de um meme, consideramos a fidelidade como um domínio de particularidades que se mantêm após o processo de variabilidade, agenciando o falante na construção desse fenômeno linguístico. A ideia de fidelidade permite ao meme estabelecer conexões e, principalmente, ser reconhecido mesmo diante das suas modificações, por meio da rememoração de enunciações e da sustentação referencial. Assim, a fidelidade se localiza no campo do repetível, podendo apresentar regularidades a partir de dois aspectos: o formal, o estrutural, ou seja, a sua materialidade; e o aspecto simbólico associado aos aspectos enunciativos que a sustentam.

No campo da irrepetibilidade se encontra a característica da fecundidade que está associada à difusão do meme na internet, à velocidade com que ele se espalha 
socialmente e, principalmente, sua capacidade de adquirir novas formas e novos significados. O que torna o meme fecundo são suas variações, suas mudanças sustentadas por sua suscetibilidade enunciativa. Tais mutações não só auxiliam na propagação dos memes, como também contribuem para a participação dos internautas através da criação de novas versões de um determinado meme. Assim, a fecundidade, a exemplo da fidelidade, também se estabelece como um processo de misturas contínuas tanto dos aspectos formais, quanto dos aspectos enunciativos ligados às (re)configurações dos efeitos de sentido. Trata-se de um dinâmico movimento do meme, responsável pela atualização e ressignificação de dizeres que, sustentados por referenciais históricos e sociais, se presentificam e encontram pertinência em enunciações cotidianas.

Desse modo, é na relação entre o mesmo e o diferente que o meme significa. Tal processo de manutenção e mutabilidade se dá por mudanças sintáticas, morfológicas, lexicais e de caráter semântico, materializadas no acontecimento enunciativo. Essas mudanças em seu funcionamento não se restringem apenas ao plano formal, nem invalidam o aspecto da fidelidade. Pelo contrário, o deslocamento linguístico possibilita o meme atuar enquanto meme, condensando e projetando sentidos variados, agenciado falantes e oferecendo possibilidades de significação por meio de múltiplas combinações.

Sobre a longevidade, percebemos que se trata da capacidade de durabilidade do meme, ou seja, de sua sobrevivência no ambiente digital. Um dos aspectos que consideramos importantes dentro dessa característica é a regularidade de uso que o meme assume em práticas discursivas, na medida em se situa no entremeio da resistência e da mudança. Assim, a manutenção de determinado meme em um espaço digital contribui para sua continuidade, mobilizando variações constantes. Reconhecemos a tendência que o meme possui em se tornar um fenômeno efêmero em função de uma massiva e variada produção. Contudo, apesar de a internet possibilitar uma capacidade de armazenamento de dados e informações que contribuem para a preservação dos memes, o fator que vai realmente determinar a longevidade do meme é a utilização. Logo, pensar o meme enquanto fenômeno linguístico significa entender que, somente através de seu uso, ele será resgatado, ressignificado e, assim, em um movimento de futuridade, projetará efeitos de sentido outros que, em rede, serão apreendidos socialmente. 
Em síntese, a partir do que foi discutido, esperamos ter demonstrado que o movimento de (re)significação do meme se realiza por meio de suas três características fundantes: a fidelidade que funciona como um conector ao estabelecer relações em rede com outros enunciados a partir da manifestação de regularidades; a fecundidade, como parte do movimento de (re)significação do meme, que produz uma quebra na noção de cópia perfeita, se distanciando do conceito de viral e se configurando pela suscetibilidade enunciativa; e a longevidade que permite o meme ser atualizado enquanto acontecimento enunciativo por meio do processo de rememoração de enunciações e sentidos.

Com efeito, essas características integram a temporalidade própria do acontecimento, uma vez que resgatam o passado pelo regular, o presentificam por meio da atualização e projetam um futuro que se desdobrará em outras enunciações efetivando o processo de enunciar.

\section{Referências}

\#TCHAUQUERIDO: afastamento de Eduardo Cunha vira meme e é um dos assuntos mais comentados nas redes sociais. Gazeta do Povo, Curitiba, 5 maio 2016. Disponível em: https://www.gazetadopovo.com.br/vida-publica/tchauquerido-afastamento-deeduardo-cunha-vira-meme-e-e-um-dos-assuntos-mais-comentados-nas-redes-sociais5dqqx5t6myz0rjedhl1ay6p94/. Acesso em: 19 jul. 2019.

'TCHAU querida' é o assunto mais comentado nas redes sociais. Ubaitaba.com, Ubaitaba, 13 maio 2016. Disponível em: http://ubaitaba.com/tchau-querida-assuntocomentado-nas-redes-sociais/. Acesso em: 19 jul. 2019.

A META. \#Museu de memes, Rio de Janeiro, 10 ago. 2015. Disponível em: http://www.museudememes.com.br/sermons/a-meta/. Acesso em: 15 jul. 2019.

BARROS, Carlos Juliano. Com medo de ameaças, Jean Wyllys, do PSOL, desiste de mandato e deixa o Brasil. Folha de São Paulo, São Paulo, 24 jan. 2019. Disponível em: https://www1.folha.uol.com.br/poder/2019/01/com-medo-de-ameacas-jean-wyllys-dopsol-desiste-de-mandato-e-deixa-o-brasil.shtml. Acesso em: 30 jan. 2019.

CASTRO, Fernando; NUNES, Samuel; NETTO, Vladimir. Moro derruba sigilo e divulga grampo de ligação entre Lula e Dilma; ouça. G 1, [s. I.], 16 mar. 2016. Disponível em: http://g1.globo.com/pr/parana/noticia/2016/03/pf-libera-documento-que-mostraligacao-entre-lula-e-dilma.html. Acesso em: 26 jan. 2019.

CHAGAS, Viktor; TOTH, Janderson Pereira. Monitorando memes em mídias sociais. In: SILVA, Tarcízio; STABILE, Max. Monitoramento e pesquisa em mídias sociais: metodologias, aplicações e inovações. São Paulo: Uva Limão, 2016. p. 211-233. 
CHEGA no ouvidinho da gata e fala: tchau, querida. Pinterest, [20--]. Disponível em: https://www.pinterest.pt/pin/287104544973633850/. Acesso em: 19 jul. 2019.

COMANDANTE do exército vê risco de crise social no país. OCC Alerta Brasil, [s. I.],14 out. 2015. Disponível em: http://occalertabrasil.blogspot.com/2015/10/comandante-doexercito-ve-risco-de.html. Acesso em: 22 jul. 2019.

DALMASCHIO, Luciani. Uma semântica de base enunciativa $x$ a construção históricopolítico-social do sentido. In: ASSUNÇÃO, AntônioLuiz; FIGUEIREDO, Ivan Vasconcelos; TOLENTINO, Eliana da Conceição; BRAGANÇA, Gustavo Moura (org.). As letras da política. Rio de Janeiro: Mauad X, 2015. p. 241-255.

DAWKINS, Richard. O gene egoísta. 12. ed. São Paulo: Companhia das Letras, 2007.

DEPUTADOS levam ao plenário cartazes de "tchau, querida" e Constituição rasgada. Jovem Pan, [s. I.], 15 abr. 2016. Disponível em: https://jovempan.uol.com.br/noticias/brasil/deputados-levam-ao-plenario-cartazes-detchau-querida-e-constituicao-rasgada.html. Acesso em: 25 jan. 2019.

DIAS, Luiz Francisco. Enunciação e relações linguísticas. Campinas: Pontes, 2018.

DIAS, Marina; FOREQUE, Flávia. Ao anunciar novas vagas, Dilma se enrola para explicar meta do Pronatec. Folha de São Paulo, São Paulo, 28 jul. 2015. Disponível em: https://www1.folha.uol.com.br/educacao/2015/07/1661345-ao-anunciar-novas-vagasdilma-se-enrola-para-explicar-meta-do-pronatec.shtml. Acesso em: 15 jul. 2019.

DILMA promete dobrar a meta que não existe. Juliano Camargo. [S. I.: s. n.], [20--]. 1 vídeo (1 min. 54). Disponível em: https://www.youtube.com/watch?v=LeWyZEW3FzU. Acesso em: 15 jul. 2019.

FLORES, Valdir Nascimento; TEIXEIRA, Marlene. Introdução à linguística da enunciação. São Paulo: Contexto, 2005.

GÓES, Bruno. Dilma sugere 'estoque de vento' e vira piada na internet. O Globo, Rio de Janeiro, 10 out. 2015. Disponível em: https://oglobo.globo.com/brasil/dilma-sugereestoque-de-vento-vira-piada-na-internet-17744645. Acesso em: 22 jul. 2019.

GUIMARÃES, Eduardo Roberto Junqueira. Semântica do acontecimento: um estudo enunciativo da designação. 4. ed. Campinas: Pontes, 2017.

GUIMARÃES, Eduardo Roberto Junqueira. Semântica: enunciação e sentido. Campinas: Pontes, 2018.

IMAGENS engraçadas. Hipertrofia.org, [20--]. Disponível em: https://www.hipertrofia.org/forum/topic/26890-imagens-engra\%C3\%A7adas-proibidopol\%C3\%ADtica-e-religi\%C3\%A3o/page/578/. Acesso em: 22 jul. 2019.

JUBÉ, Andrea. Em noite inspirada, Dilma saúda mandioca e fala em "mulheres sapiens". Valor Econômico, São Paulo, 23 jun. 2015. Disponível em: https://valor.globo.com/politica/noticia/2015/06/23/em-noite-inspirada-dilma-sauda- 
mandioca-e-fala-em-mulheres-sapiens.ghtml. Acesso em: 23 jul. 2019.

LOPES, Daniel. Estamos diante de um raro caso de involução de um pensamento não evoluído. Amálgama, [s. I.], 9 jan. 2016. Disponível em:

https://www.revistaamalgama.com.br/01/2016/celso-arnaldo-araujo-dilmes-entrevista/. Acesso em: 23 jul. 2019.

LORENZO, Antonio. Dobrar a meta, caro amigo @alexandregarcia?: cuidado com os direitos autorais da frase, hein?? [S. I.], 26 mar. 2019. Twiter: @lorenzof5. Disponível em: https://twitter.com/lorenzof5/status/1110726039452434432. Acesso em: 20 jul. 2019.

MARTELLO, Alexandro; CALGARO, Fernanda; MATOSO, Filipe; GARCIA, Gustavo; ALEGRETTI, Laís; PASSARINHO, Nathalia; RAMALHO, Renan. Câmara aprova prosseguimento do processo de impeachment no Senado. G 1, [s. I.], 17 abr. 2016. Disponível em: http://g1.globo.com/politica/processo-de-impeachment-dedilma/noticia/2016/04/camara-aprova-prosseguimento-do-processo-de-impeachmentno-senado.html. Acesso em: 25 jan. 2019.

MR ANT. O Aécio plantou vento e Dilma queria estocar. [S. I.], 19 mar. 2018. Twitter: @Felipe_Hormiga. Disponível em:

https://twitter.com/Felipe_Hormiga/status/975845230451789825. Acesso em: 22 jul. 2019.

MULHER sapiens. Ataque Aberto, 26 jun. 2015. Disponível em: https://ataqueaberto.blogspot.com/2015/06/mulher-sapiens.html. Acesso em: 23 jul. 2019.

OLIVEIRA, Mariana; RAMALHO, Renan. Ministro do STF afasta Cunha do mandato e da presidência da Câmara. G1, São Paulo, 5 maio 2016. Disponível em: http://g1.globo.com/politica/noticia/2016/05/teori-determina-afastamento-de-cunha-domandato.html. Acesso em: 30 jan. 2019.

PONTES, Eunice. O tópico no português do Brasil. Campinas: Pontes, 1987.

RAZÃO 17. Tchau querida!!!! Kakakakakaka. [S. I.], 25 jan. 2019. Twitter: @razão17. Disponível em: https://twitter.com/Razao17/status/1088784588913156101. Acessoem: 30 jan. 2019.

ROSSET, Tatiane. Todo mundo fez a mesmapiada com o Rubinho Barrichello nestedomingo (17). Veja, São Paulo, 26 fev. 2017. Disponível em: https://vejasp.abril.com.br/blog/pop/todo-mundo-fez-a-mesma-piada-com-o-rubinhobarrichello-neste-domingo-17/. Acesso em: 19 jul. 2019.

SHIFMAN, Limor. An anatomy of a YouTube meme. New Media \& Society, New York, v. 14, n. 2, p. 187-203, 2012.

SHIFMAN, Limor. Memes in a digital culture. Cambridge: MIT, 2014. 
TCHAU, mulher sapiens. Pinterest, [20--]. Disponívelem:

https://br.pinterest.com/pin/184366178474978564/. Acesso em: 23 jul. 2019.

THAINÁ. Meu voto não foi em vão... tchau diega vai fazer companhia pro Gustavo kkkk. [S. I.], 12 fev. 2019. Twitter: @thaycardenas. Disponível em:

https://twitter.com/thaycardenas/status/1095498875190824960. Acesso em: 19 jul. 2019.

Submetido em: 17 fev. 2020.

Aceito em: 15 dez. 2020. 